Gazi University
Journal of Science
PART A: ENGINEERING AND INNOVATION
http://dergipark.org.tr/gujsa

\title{
Bioactivities from Novel Toxins of Pterois volitans: A Bioinformatics Approach
}

\author{
Levent CAVAS $^{12 *(D)}$, Yagmur BILGIN ${ }^{1(i D)}$ \\ ${ }^{I}$ Department of Chemistry, Faculty of Science, Dokuz Eylül University, İzmir, Turkey 35390, Kaynaklar Campus \\ ${ }^{2}$ Department of Biotechnology, Graduate School of Natural and Applied Sciences, Dokuz Eylül University, Izmir, Turkey 35390, Kaynaklar Campus
}

\begin{tabular}{|c|c|}
\hline Keywords & Abstract \\
\hline $\begin{array}{l}\text { Angiotensin Converting } \\
\text { Enzyme } \\
\text { Bioactive Peptides } \\
\text { Dipeptidyl Peptidase-IV } \\
\text { Pterois volitans }\end{array}$ & $\begin{array}{l}\text { Pterois volitans (Linnaeus, 1758), native of the Indo-Pacific Ocean, is an invasive fish species in the } \\
\text { Western-Atlantic. Due to the very long venomous spines, they increase their populations in newly } \\
\text { invaded habitats. No validated eradication method has been existed for this species yet. Therefore, there } \\
\text { is an urgent need for alternative utilization methods for this fish species. Bioactive peptides are of great } \\
\text { importance for human health since they exhibit excellent inhibitory properties for some medicinally } \\
\text { important enzymes in human metabolisms such as angiotensin converting enzyme (ACE) and dipeptidyl } \\
\text { peptidase-IV (DPP-IV). In this study, the bioactive peptides in protein-based venom of } P \text {. volitans, } \\
\text { Pvtoxin-a and Pvtoxin-b, were investigated by using in silico tools. Total number of negatively charged } \\
\text { residues (Asp + Glu) for Pvtoxin-a and Pvtoxin-b were found as } 21 \text { and } 18 \text {, respectively. Total number } \\
\text { of positively charged residues (Arg + Lys) for Pvtoxin-a and Pvtoxin-b were observed to be } 22 \text { and } 24 \text {, } \\
\text { respectively. According to BIOPEP results, AE values for ACE and DPP-IV were found to be } 0.0305 \\
\text { and } 0.0666 \text { for Pvtoxin-a and Pvtoxin-b as } 0.0333 \text { and } 0.0569 \text {, respectively. It is very interesting to note } \\
\text { that AE values related to antioxidant property were observed to be } 0.0083 \text { for both Pvtoxin-a and Pvtoxin- } \\
\text { b. Although AE value for alpha-glucosidase inhibitor was found to be } 0.0014 \text { for Pvtoxin-a, no AE value } \\
\text { was obtained for Pvtoxin-b. In conclusion, the BIOPEP results clearly show that after a possible } \\
\text { eradication study, protein-based venoms from } P \text {. volitans can be evaluated in the production of bioactive } \\
\text { peptides. A possible economical value may create a pressure on its increasing population in newly } \\
\text { invaded areas. }\end{array}$ \\
\hline
\end{tabular}

\begin{tabular}{lcc}
\hline Cite & \\
\hline Cavas, L., \& Bilgin, Y. (2021). Bioactivities from Novel Toxins of Pterois volitans: A Bioinformatics Approach. GU J Sci, Part A, \\
$8(4)$, 411-423. & Article Process \\
\hline Author ID (ORCID Number) & Submission Date & 30.09 .2021 \\
\hline L. Cavas, 0000-0003-2136-6928 & Revision Date & 01.11 .2021 \\
Y. Bilgin, 0000-0002-1999-6050 & Accepted Date & 08.11 .2021 \\
& Published Date & 12.11 .2021 \\
\hline
\end{tabular}

\section{INTRODUCTION}

The entry of invasive species has been increasing and becoming a major problem in the Mediterranean Sea (Carballo-Cárdenas, 2015; Bédry et al., 2021). The name "lionfish" is given for the members of the genera Pterois, Parapterois and Dendrochirus. Among this large family, Pterois volitans (Linnaeus, 1758) and P. miles (Bennett, 1828) (Actinoptery: Scorpaeniformes: Scorpaenidae) are of great importance due to their invasive properties. The lionfish invasion is one of the important concerns for marine ecosystems since they have an ability to alter native fish populations and damage to the native biodiversity (Sutherland et al., 2010; Andradi-Brown, 2019). Although P. volitans are native to the western parts of the Indo-Pacific Ocean, they have so far been reported from western Atlantic (Schofield, 2009; 2010), USA (Meister et al., 2005) and southeast Brazil (Ferreira et al., 2015). The invasion of lionfish has still been confused for the Mediterranean Sea due to some published reports in the scientific journals. As an example, although some authors (Gürlek et al., 2016; Turan et al., 2017; 2020, Ayas et al., 2018) previously identified the lionfish in the Mediterranean Sea coastline of Turkey as P.volitans, according to the recent papers by Ulman et al. (2020) and Cinar et al. (2021), the lionfish off the Turkish coastline is defined as $P$. miles. The reason of the confusion is based on the misinterpretation of the samples due to i) morphological properties cannot be enough to distinguish P.volitans 
and P.miles, ii) correct bio-sequences should be selected to identify correct taxon in the genetic studies (Ulman et al., 2020; Cinar et al., 2021, Kovačić et al., 2021 ). Lionfish invasion along Turkish coastline is in increasing trend. It is very important to note that the lionfish is also mentioned in the recent novel of Zülfü Livaneli, one of the famous writers in Turkey, titled "Balıkçı ve Oğlu" (Livaneli, 2021). The lionfish has venomous dorsal spiky rays and pectoral fins (Dağhan \& Demirhan, 2020). Therefore, hunting of lionfish through spear fishing is dangerous and also risky because of its venomous spines. On the other hand, spear fishing tournaments specific to lionfish organized by various local organizations to reduce their numbers on the shores (Antalya Büyükşehir Belediyesi, 2021). However, this kind of organizations must be carried out by experts. Yuzvik et al. (2018) developed a submarine robot which has properties of hunting lionfish to control of P. volitans population in the Caribbean. Therefore, it could be stated that lionfish may harm the ecosystem due to their huge appetites and preferences for native species, however they may also present economic benefits through development of commercial fisheries for them (Kleitou et al., 2019). It has maroon or brown and white stripes (Davis, 2016) also it has 13 back, 3 anal spines and one on each pelvic fin (Galloway \& Porter, 2019). P. volitans uses its back spines to present itself larger and stronger (Galloway \& Porter, 2019). Its spines contain non-protein based ichthyotoxin with low molecular mass. This venom can be isolated from only alive fishes (Nair et al., 1985). Toxins can cause to symptoms that last for a few days as a result of contact with humans. Burning symptom is observed within the first 15-20 minutes after the spines come into contact. Also, tachycardia, hypertension, and numbness can be observed. After 3 hours, the venom spreading into the body can cause limb paralysis (Vetrano et al., 2002). Therefore, it is dangerous if the spines penetrate humans, but once their spines are removed, they are safe to consume and are considered a very delicious fish. The lionfish is at the top of the underwater food chain and is a major threat to native fish. P. volitans is observed in the ecosystem where it skillfully hunts smaller fish and crustaceans. It damages native biodiversity. Especially, the Mediterranean Sea and the Caribbean are under the threat since lionfish has widely distributed areas in these marine ecosystems (Carballo-Cárdenas, 2015; Ulman et al., 2020).

Bioactive peptides are obtained from food proteins. They are component of the functional foods and nutraceuticals and therefore they play important roles in human health (Liu et al., 2020). Hyperlipidemia, inflammation, diabetes, cancer, immune disorder can be given as example disorders in which bioactive peptides can show effectiveness (Agyei \& Danquah, 2012). They are related with biological activities such as antimicrobial, antioxidant, antihypertensive, immunomodulatory, antidiabetes, anti-cancer (Daroit \& Brandelli, 2021). Bioactive peptides consist of 2-20 amino acid residues. Long peptides are inactive without hydrolysis. They are activated via hydrolysis methods such as fermentation (proteolytic enzymes, microbial or vegetable proteolytic enzymes) (Weaver, 2014). Compared to proteins, bioactive peptides are absorbed by the intestine completely due to their sizes (Zhou et al., 2020). Bioactive peptides are new to humans but safety studies have been limited yet for commercial use although they are derived from foods. There has so far been no information yet about if new bioactive peptides carry sequences with allergenic or even toxic (Liu et al., 2020). The origin of bioactive peptides can be plant or animal. Grains and legumes are peptide rich sources (Jang \& Lee, 2005). According to Chakrabarti et al. (2018), there are three challenges on the utilization of food-derivated bioactive peptides and they are production, oral consumption and regulation. Bioactive peptides may be used for the chronic diseases but further studies are required.

Kiriake \& Shiomi (2011) discovered two proteinaceous toxins from two lionfish species (Pterois antennata and Pterois volitans). The authors investigated the toxin structures via cDNA cloning using primers designed from the highly conserved sequences of the stonefish toxins. Since these toxins homologous are most probably existed in Scorpaeniformes members (Kiriake \& Shiomi, 2011), P. miles which has a second colonization in the Mediterranean Sea may have these toxins and may show similar symptoms when preys are exposed to these toxins. P. miles is also widely distributed within the Mediterranean Sea, we wanted to investigate bioactive peptides in Pvtoxin-a and Pvtoxin-b in P.volitans by using bioinformatics tools developed for identification of bioactive peptides within protein sequences.

\section{MATERIALS AND METHODS}

The proteins related to $P$. volitans were searched by using UniProt.org and 560 proteins were listed. The longest protein was Pvtoxin-a (F2ZAF0) with 699 amino acids and the shortest protein was ATP synthase protein 8 (A0A0U1WQN3) with 55 amino acids (Morgat et al., 2020). In this study, Pvtoxin-a (F2ZAF0) and 
Pvtoxin-b (F2ZAF1) were selected as model proteins. FASTA formats of proteins were obtained from UniProt.org. In order to obtain protein parameters, Protparam tool was used (Gasteiger et al., 2005). Pairwise sequence alignment was carried out by using Clustal Omega (Sievers et al., 2011). BIOPEP-UWM (http://www.uwm.edu.pl/biochemia/index.php/en/biopep) was used to estimate bioactive peptides in Pvtoxin$\mathrm{a}$ and Pvtoxin-b. Chymotrypsin, trypsin and pepsin $(\mathrm{pH}=1.3)$ were used for in silico digestions. The reason for selection of these 3 proteolytic enzymes was their importance in human protein digestion system (Minkiewicz et al., 2019). The analytical parameters with respect to bioactive peptides were estimated from BIOPEP-UWM and then they were compared. The Basic Local Alignment Search Tool (BLAST) was used to find similar proteins in the protein database.

\section{RESULTS}

\subsection{Protparam Results}

Protein parameters in Pvtoxin-a and -b were studied in this paper by using Protparam tool (Gasteiger et al., 2005). According to Table 1, most two abundant amino acids in Pvtoxin-a were leucin (\% 8.8) and valine (\% 7.7). Maximum percentages of amino acids in Pvtoxin-b were found as leucine (\% 7.8) and glycine and lysine (\% 7.3). From the results, it could be said that essential amino acid leucine is very high in both studied proteins. Theoretical pI value was found for Pvtoxin-a as 7.89 and for Pvtoxin-b as 9.14. Total number of negatively charged residues (Asp + Glu) for Pvtoxin-a and Pvtoxin-b were found as 21 and 18, respectively. Total number of positively charged residues (Arg + Lys) for Pvtoxin-a and Pvtoxin-b were observed to be 22 and 24, respectively. It is very interesting to note that the net charges of the proteins studied, Pvtoxin-a and Pvtoxin-b, were found as 1 and 6 , respectively.

Table 1. Number, Percentages and Theoretical PI, Total Number of Positively \& Negatively Charged Residues and Net Charge of Amino Acids of Pvtoxin-a and Pvtoxin-b Proteins of Pterois volitans (aa: amino acids)

\begin{tabular}{|c|c|c|c|c|}
\hline & \multicolumn{2}{|c|}{ Pvtoxin-a } & \multicolumn{2}{|c|}{ Pvtoxin-b } \\
\hline & \#аa & aа\% & \#аa & aa\% \\
\hline Ala (A) & 6 & 3.1 & 10 & 5.2 \\
\hline $\operatorname{Arg}(\mathbf{R})$ & 8 & 4.1 & 10 & 5.2 \\
\hline $\operatorname{Asn}(\mathbf{N})$ & 14 & 7.2 & 8 & 4.1 \\
\hline Asp (D) & 10 & 5.2 & 11 & 5.7 \\
\hline Cys (C) & 3 & 1.5 & 4 & 2.1 \\
\hline $\operatorname{Gln}(\mathbf{Q})$ & 5 & 2.6 & 10 & 5.2 \\
\hline Glu (E) & 11 & 5.7 & 7 & 3.6 \\
\hline Gly (G) & 14 & 7.2 & 14 & 7.3 \\
\hline His (H) & 8 & 4.1 & 6 & 3.1 \\
\hline Ile (I) & 9 & 4.6 & 10 & 5.2 \\
\hline Leu $(\mathrm{L})$ & 17 & 8.8 & 15 & 7.8 \\
\hline Lys (K) & 14 & 7.2 & 14 & 7.3 \\
\hline Met (M) & 3 & 1.5 & 1 & 0.5 \\
\hline Phe (F) & 10 & 5.2 & 1 & 5.7 \\
\hline Pro (P) & 10 & 5.2 & 10 & 5.2 \\
\hline Ser (S) & 14 & 7.2 & 12 & 6.2 \\
\hline Thr (T) & 10 & 5.2 & 12 & 6.2 \\
\hline $\operatorname{Trp}(\mathrm{W})$ & 5 & 2.6 & 8 & 4.1 \\
\hline $\operatorname{Tyr}(Y)$ & 8 & 4.1 & 8 & 4.1 \\
\hline Val (V) & 15 & 7.7 & 12 & 6.2 \\
\hline Theoretical pI & \multicolumn{2}{|c|}{7.89} & \multicolumn{2}{|c|}{9.14} \\
\hline $\begin{array}{l}\text { Total number of negatively charged } \\
\text { residues (Asp + Glu): }\end{array}$ & \multicolumn{2}{|c|}{21} & \multicolumn{2}{|c|}{18} \\
\hline $\begin{array}{c}\text { Total number of positively charged } \\
\text { residues (Arg + Lys): }\end{array}$ & \multicolumn{2}{|c|}{22} & \multicolumn{2}{|c|}{24} \\
\hline Net charge & \multicolumn{2}{|c|}{1} & \multicolumn{2}{|c|}{6} \\
\hline
\end{tabular}




\subsection{Pairwise Sequence Alignment results}

Clustal Omega tool was used to determine the similarity of Pvtoxin-a and -b (Siever et al., 2011). According to Figure 1, their both N-terminals are methionine (M) and their C-terminals are leucine (L), respectively. There is very high similarity in the amino acid sequences of the proteinous toxins, Pvtoxin-a and $-\mathrm{b}$.

\begin{tabular}{|c|c|}
\hline $\begin{array}{l}\operatorname{tr}|F 2 Z A F O| \\
\operatorname{tr}|F 2 Z A F 1|\end{array}$ & $\begin{array}{l}\text { MSSEILIVAALGRPFTLGALYDSRKDRLIPGFTLWEDDVLQANTVESRQPSSAFEIIASD } \\
\text { MSSQILVVAALGRPFTLGTLYDARKVRLIPGFTLWEDDVLANTVESRQPSSAFEIIASD } \\
* * *: * *: * * * * * * * * * * * * * *: * * * * * * * * * * * * * * * * * * * * * * * * * * * * * * * *\end{array}$ \\
\hline $\begin{array}{l}\operatorname{tr}|F 2 Z A F O| \\
\operatorname{tr}|F 2 Z A F 1|\end{array}$ & 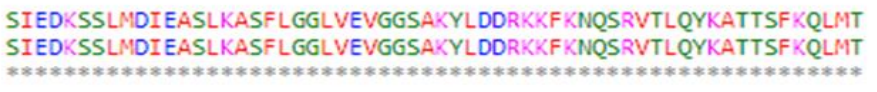 \\
\hline $\begin{array}{l}\operatorname{tr}|F 2 Z A F O| \\
\operatorname{tr}|F 2 Z A F 1|\end{array}$ & $\begin{array}{l}\text { NLETKHVEYSEYFONLEATHWIGILYGANAFFVFDSAKTESSNVQOIQGSMEAAIKKIP } \\
\text { NLETKHVEYSEYFONLEATHVFIGILYGANAFFVFDSAKTESSNVQOIQGSMEAAIKKIP } \\
* * * * * * * * * * * * * * * * * * * * * * * * * * * * * * * * * * * * * * * * * * * * * * * * * * * *\end{array}$ \\
\hline $\begin{array}{l}\operatorname{tr}|F 2 Z A F \theta| \\
\operatorname{tr}|F 2 Z A F 1|\end{array}$ & 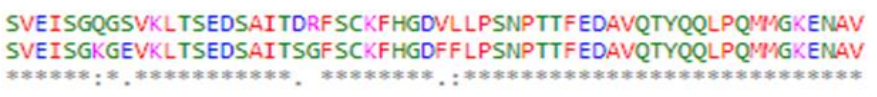 \\
\hline $\begin{array}{l}\operatorname{tr}|F 2 Z A F 0| \\
\operatorname{tr}|F 2 Z A F 1|\end{array}$ & $\begin{array}{l}\text { PMKVWLVPLVHFYSEAPKLMADSSISILRRVRNTLEAMRELEMRCNDALEDNTVKLFPLM } \\
\text { PMTVWLVPLVWFYSEAPKLMADSSTPILRKVRNTLEAMRELEMRCNDALEDNTVKLFPLI } \\
* * * * * * * * *: * * * * * * * * * * * * * * * * * * * * * * * * * * * * * * * * * * * * * * * * *\end{array}$ \\
\hline $\begin{array}{l}\operatorname{tr}|F 2 Z A F \theta| \\
\operatorname{tr}|F 2 Z A F 1|\end{array}$ & 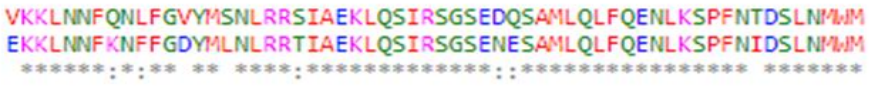 \\
\hline $\begin{array}{l}\operatorname{tr}|\mathrm{F} 2 \mathrm{ZAF} 0| \\
\operatorname{tr}|\mathrm{F} 2 \mathrm{ZAF} 1|\end{array}$ & $\begin{array}{l}\text { DCAEREINVLRSCIDIIEEARHKWLSESEMFRELLDSNVKHAVCWFTFVTDQDPFLKV } \\
\text { DCAEREINVLRSCIDIIEEARHKWVLSESEMFRELLDPNVKHAVCWFTFVTDQDPFLNV } \\
* * * * * * * * * * * * * * * * * * * * * * * * * * * * * * * * * * * * * * * * * * * * * * * * * * * * *\end{array}$ \\
\hline $\begin{array}{l}\operatorname{tr}|F 2 Z A F O| \\
\operatorname{tr}|F 2 Z A F 1|\end{array}$ & $\begin{array}{l}\text { LTDYLDSPDSRPKRTRPPATEWIYASDTIPEMIIRDKAHIFYNLAKEIMDNRRVRFLVASIV } \\
\text { LSDFLDSPTSKPKKLRPSTKDWIYISDDIPEMIRAKAHHFRNLALDIDNRCVRFLVASIG } \\
*: *: * * * * *: * *: * *: ;: * * * * * * * * * * * * * * * * * *: * * * * * * * * * * * *\end{array}$ \\
\hline $\begin{array}{l}\operatorname{tr}|F 2 Z A F O| \\
\operatorname{tr}|F 2 Z A F 1|\end{array}$ & $\begin{array}{l}\text { NPKQEGAGIHYYRENILIEQEFLQPKMINPVEKIVDRRDLLWCDCELTLDPVTAHPALTLS } \\
\text { NPKQEGAGIHYYREGIQIIDEFTKPIVIPPVETIQDRRELLWCDCELTLDPDTAQPALTLS } \\
* * * * * * * * * * * * * * *: * *: *: * * * ; * * * ; * * * * * * * * * * * ; * * * * *\end{array}$ \\
\hline $\begin{array}{l}\operatorname{tr}|F 2 Z A F O| \\
\operatorname{tr}|F 2 Z A F 1|\end{array}$ & $\begin{array}{l}\text { EGNKKAVSGKPKPSDNNPERFEHFQWLCKKQLIRRHYWEIKWSGFVGAGVIRNSIHPKS } \\
\text { EGNKKAVSGTAKPFDNQQRRFQCYQQVLCNKGLSRRHYWEVEWSGWRAGVTYKGISRRT } \\
* * * * * * * * * . * * * *: . * *:: * * * *: * * * * * * *:: * * *: * * * *: 0^{*}::\end{array}$ \\
\hline $\begin{array}{l}\operatorname{tr}|F 2 Z A F O| \\
\operatorname{tr}|F 2 Z A F 1|\end{array}$ & 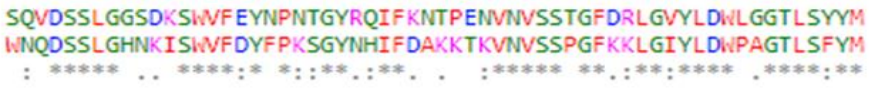 \\
\hline $\begin{array}{l}\operatorname{tr}|F 2 Z A F 0| \\
\operatorname{tr}|F 2 Z A F 1|\end{array}$ & $\begin{array}{l}\text { INNNFVTHLHTFHTLFKEAVYPAFMIGDKQNVHGEIELL } 699 \\
\text { VDTIWVTHIHTFKARFQEAVFPAFLIGHGPD-NGQIKLL } 698 \\
:::^{* * *}: * * *:: *: * * *: * *: * * . \quad::^{*}: * * *\end{array}$ \\
\hline
\end{tabular}

Figure 1. Clustal Omega Results of Pvtoxin-a and Pvtoxin-b. ('*' symbol is used to show conserved residues, ':' symbol used to show very similar amino acids in terms of physicochemical characters and :' symbol is used to show similar amino acids in terms of physicochemical characters. Empty spaces are used for deleted or inserted amino acids)

\subsection{BIOPEP-UWM Results}

BIOPEP-UWM was used for in silico hydrolysis of bioactive peptides which are obtained from Pvtoxin-a and -b (Minkiewicz et al., 2019). When Table 2 is examined, DHt value of Pvtoxin-a was found as 40.1389. $A_{E}$ value corresponds to the frequency of release of fragments by selected enzymes. $A_{E}$ values related to dipeptidyl peptidase-III and -IV inhibitors were as 0.0042 and 0.066 , respectively. $A_{E}$ values of Angiotensin converting Enzyme (ACE) inhibitor as 0.0305 . The $\mathrm{A}_{\mathrm{E}}$ values related to other bioactivities such as stimulating, antioxidative, renin inhibitor, CaMPDE inhibitor and alpha-glucosidase inhibitor can also be found in Table 2. According to Table 3, DHt value of Pvtoxin-b was found as 39.7775. The $A_{E}$ values were found for dipeptidyl peptidase-III and -IV inhibitors to be 0.0069 and 0.0569 , respectively. The $A_{E}$ values with respect to ACE inhibitor as 0.0333 . The other bioactivities such as antiamnestic, stimulating, antioxidative and renin inhibitor were depicted in Table 3. 
Table 2. In Silico Hydrolysis of Pvtoxin-a Protein of Pterois volitans Using BIOPEP-UWM Database

\begin{tabular}{|c|c|c|c|c|c|}
\hline \multicolumn{6}{|c|}{ DHt [\%] 40.1389} \\
\hline No & Activity & $\mathbf{A}_{\mathbf{E}}$ & $\mathbf{W}$ & $\mathbf{B}_{\mathbf{E}}$ & $\mathbf{V}$ \\
\hline 1 & ACE inhibitor & 0.0305 & 0.0830 & 0.0023 & 0.1357 \\
\hline 2 & Stimulating & 0.0055 & 0.1134 & 0 & $\mathrm{Nd}$ \\
\hline 3 & Antioxidative & 0.0083 & 0.1273 & 0 & 0 \\
\hline 4 & renin inhibitor & 0.0042 & 0.1317 & 0.0002 & 0.3332 \\
\hline 5 & CaMPDE inhibitor & 0.0014 & 0.1687 & 0 & nd \\
\hline 6 & dipeptidyl peptidase IV inhibitor & 0.0666 & 0.1109 & 0.0001 & 0.2552 \\
\hline 7 & alpha-glucosidase inhibitor & 0.0014 & 0.0530 & $6.1370 \mathrm{E}-5$ & 0.9683 \\
\hline 8 & dipeptidyl peptidase III inhibitor & 0.0042 & 0.0445 & 0 & nd \\
\hline
\end{tabular}

Table 3. In Silico Hydrolysis of Pvtoxin-b Protein of Pterois volitans Using BIOPEP-UWM Database

\begin{tabular}{|c|l|c|c|c|c|}
\hline \multicolumn{1}{|l}{ DHt [\%] 39.7775 } & $\mathbf{A}_{\mathbf{E}}$ & $\mathbf{W}$ & $\mathbf{B}_{\mathbf{E}}$ & $\mathbf{V}$ \\
\hline $\mathbf{N o}$ & Activity & 0.0014 & 0.2500 & $2.9551 \mathrm{E}-5$ & 1 \\
\hline $\mathbf{1}$ & antiamnestic & 0.0028 & 0.0695 & 0 & \\
\hline $\mathbf{2}$ & stimulating & 0.0333 & 0.0885 & 0.0010 & 0.0905 \\
\hline $\mathbf{3}$ & ACE inhibitor & 0.0083 & 0.1390 & 0 & 0 \\
\hline $\mathbf{4}$ & antioxidative & 0.0569 & 0.0962 & 0.0001 & 0.2193 \\
\hline $\mathbf{5}$ & dipeptidyl peptidase IV inhibitor & 0.0042 & 0.1317 & $8.9606 \mathrm{E}-7$ & 0.0058 \\
\hline $\mathbf{6}$ & renin inhibitor & 0.0069 & 0.0776 & 0 & \\
\hline $\mathbf{7}$ & dipeptidyl peptidase III inhibitor & \\
\hline
\end{tabular}

\subsection{BLAST Results}

In order to find similar proteins, BLAST-p analysis was carried out by using BLAST server (Altschul et al., 1990). Blast-p results of Pvtoxin-a and -b were given in Figure 2 and Figure 3, respectively. Pvtoxin-a like proteins were also existed in the member of same genus such as P.lunulata and P.antennata. However, similar proteins are also existed in different genus such as Scorpaenopsis, Sebastapistes, Dendrochrius and Hypodytes. The Pvtoxin-a is highlighted as yellow in Figure 2. The BLAST-p results for Pvtoxin-b were given Figure 3. Contrary to Pvtoxin-a, Tx gamma-subunit from Dendrochrius zebra was in the same clade with Pvtoxin-b. Very similar proteins with most probably same bioactivities are existed in the genus of Inimicus, Sebastepisces, Scorpaenopsis, Scorpaena, Sebastes, Sebastiscus, Dendrochrius and Hypodytes (Figure 3). The Pvtoxin-b is highlighted as yellow in Figure 3. Table 4-5 show codes and names of the proteins in the phylogenetic tree. Since Pvtoxin-a and -b are searched, the original sequences were also found after BLAST search. 


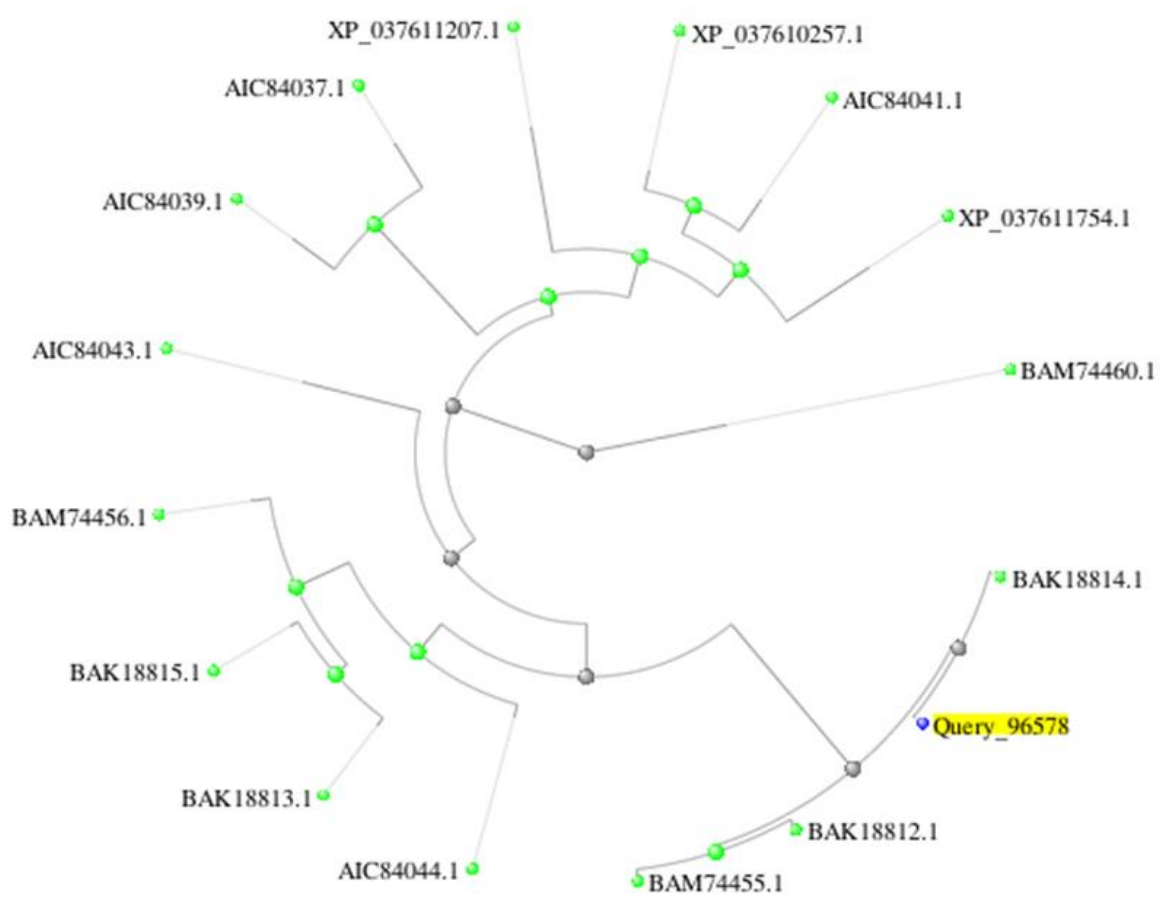

Figure 2. BLAST-p Analysis Results for Pvtoxin-a

(The Codes and Names of the Proteins are Explained in the Table 4)

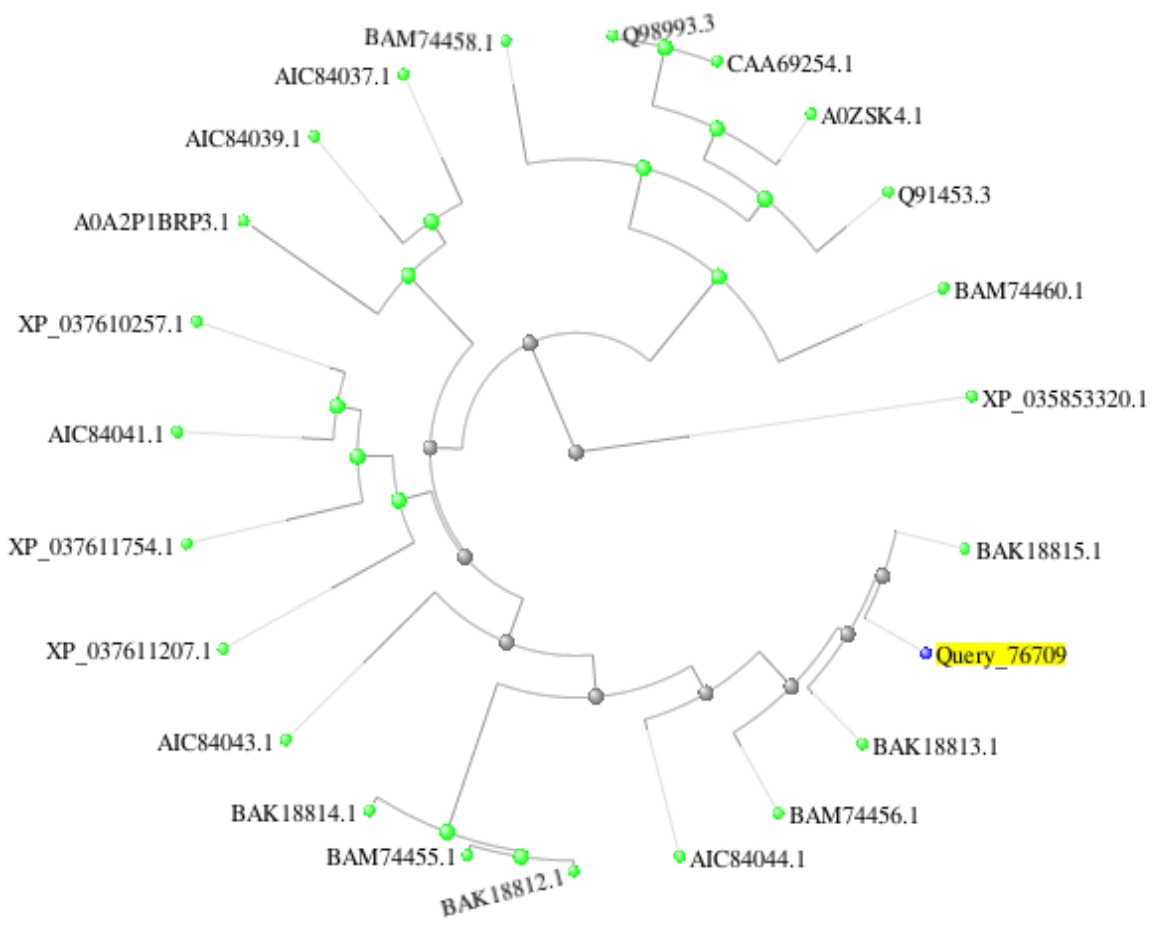

Figure 3. BLAST-p Analysis Results for Pvtoxin- $b$

(The Codes and Names of the Proteins are Explained in the Table 5) 
Table 4. A list of the codes and names of proteins obtained for Pvtoxin-a from BLAST-p

\begin{tabular}{|c|c|}
\hline The Codes & The Name of The Proteins \\
\hline Query_96578 & pvtoxin-a [Pterois volitans] \\
\hline BAK18814.1 & pvtoxin-a [Pterois volitans] \\
\hline BAM74455.1 & pltoxin-a subunit [Pterois lunulata] \\
\hline BAK18812.1 & patoxin-a subunit [Pterois antennata] \\
\hline BAM74456.1 & pltoxin-b subunit [Pterois lunulata $]$ \\
\hline BAK18815.1 & pvtoxin-b [Pterois volitans] \\
\hline BAK18813.1 & patoxin-b subunit [Pterois antennata] \\
\hline XP_037611754.1 & stonustoxin subunit beta-like [Sebastes umbrosus] \\
\hline AIC84041.1 & Tx beta-subunit [Sebastiscus marmoratus] \\
\hline AIC84037.1 & Tx beta-subunit [Sebastapistes strongia] \\
\hline XP_037610257.1 & stonustoxin subunit beta-like [Sebastes umbrosus] \\
\hline XP_037611207.1 & stonustoxin subunit beta-like [Sebastes umbrosus] \\
\hline AIC84039.1 & Tx beta-subunit [Scorpaenopsis oxycephala] \\
\hline AIC84044.1 & Tx gamma-subunit [Dendrochirus zebra] \\
\hline BAM74460.1 & hrtoxin-b subunit [Hypodytes rubripinnis] \\
\hline AIC84043.1 & Tx beta-subunit [Dendrochirus zebra] \\
\hline
\end{tabular}


Table 5. A list of the codes and names of proteins obtained for Pvtoxin- $b$ from BLAST-p

\begin{tabular}{|c|c|}
\hline The Codes & The Name of The Proteins \\
\hline Query_76709 & pvtoxin-b [Pterois volitans] \\
\hline BAK18815.1 & pvtoxin-b [Pterois volitans] \\
\hline BAK18813.1 & patoxin-b subunit [Pterois antennata] \\
\hline BAM74456.1 & pltoxin-b subunit [Pterois lunulata] \\
\hline XP_037610257.1 & stonustoxin subunit beta-like [Sebastes umbrosus] \\
\hline AIC84041.1 & Tx beta-subunit [Sebastiscus marmoratus] \\
\hline AIC84037.1 & Tx beta-subunit [Sebastapistes strongia] \\
\hline BAK18814.1 & pvtoxin-a [Pterois volitans] \\
\hline AIC84044.1 & Tx gamma-subunit [Dendrochirus zebra] \\
\hline BAM74455.1 & pltoxin-a subunit [Pterois lunulata] \\
\hline XP_037611207.1 & stonustoxin subunit beta-like [Sebastes umbrosus] \\
\hline BAK18812.1 & patoxin-a subunit [Pterois antennata $]$ \\
\hline AIC84039.1 & Tx beta-subunit [Scorpaenopsis oxycephala] \\
\hline XP_037611754.1 & stonustoxin subunit beta-like [Sebastes umbrosus] \\
\hline BAM74460.1 & hrtoxin-b subunit [Hypodytes rubripinnis] \\
\hline Q91453.3 & $\begin{array}{l}\text { RecName: Full=Stonustoxin subunit beta; Short=SNTX subunit beta; AltName: } \\
\text { Full=DELTA-synanceitoxin-Sh1b; Short=DELTA-SYTX-Sh1b; AltName: } \\
\text { Full=Trachynilysin subunit beta; Short=TLY subunit beta [Synanceia horrida }]\end{array}$ \\
\hline A0ZSK4.1 & $\begin{array}{l}\text { RecName: Full=Neoverrucotoxin subunit beta; Short=NeoVTX subunit beta } \\
{[\text { Synanceia verrucos }]}\end{array}$ \\
\hline XP_035853320.1 & LOW QUALITY PROTEIN: stonustoxin subunit beta-like [Sander lucioperca] \\
\hline BAM74458.1 & ijtoxin-b subunit [Inimicus japonicus] \\
\hline A0A2P1BRP3.1 & RecName: Full=Cytolytic toxin-beta; Short=Sp-CTx-beta [Scorpaena plumieri $]$ \\
\hline AIC84043.1 & Tx beta-subunit [Dendrochirus zebra] \\
\hline CAA69254.1 & verrucotoxin alpha [Synanceia verrucosa] \\
\hline Q98993.3 & $\begin{array}{l}\text { RecName: Full=Verrucotoxin subunit beta; Short=VTX subunit beta [Synanceia } \\
\text { verrucosa] }\end{array}$ \\
\hline
\end{tabular}




\section{DISCUSSION}

Introduction of alien or non-indigenous species into a new habitat may not always harm to ecosystem. In order to define an alien species as an invasive species, alien species must negatively impact the biodiversity, economy or human health (Ulman et al., 2020). As an example, P.miles invasion in the Mediterranean Sea coastline of Turkey impressed not only scientists, but also writers. Lionfish invasion and its social effects from the eyes of a local fisherman in Turkey are described in the recent novel of Zülfü Livaneli (Livaneli, 2021). The current situation of P.volitans in Turkey is also complicated due to previously published and confused papers where the lionfish is defined as P.volitans (Gürlek et al., 2016; Turan et al., 2017; 2020, Ayas et al., 2018), on the other hand, recent papers underline that the lionfish in Turkish coastlines is P.miles (Ulman et al., 2020; Çinar et al., 2021). Bioactive peptides are obtained via wet lab studies. The bioinformatic tools are also used for discovering of bioactive peptides (Agirbasli \& Cavas, 2017; Kandemir-Cavas et al., 2019). In this study, Pvtoxin-a and Pvtoxin-b from P. volitans were studied as model proteins. Amino acid sequences were compared by using well-known bioinformatics tools such as Protparam and multiple sequence alignment. The novelty of the paper is to study BIOPEP parameters of Pvtoxin-a and Pvtoxin-b from $P$. volitans. There are some differences in protein parameters in Pvtoxin-a and Pvtoxin-b from P. volitans such as theoretical pI, net charge and total number of negatively and positively charged residues (Table 1). These differences are caused by the amino acid sequence variations in these proteins (Figure 1). These toxins are still classified as unreviewed proteins in the uniprot.org. However, based on the sequence homology, it is said that these proteins show their functions outside the cell membranes since they are toxin-based proteins. Since they are long protein, consisted of more than 698 amino acids, their short-bioactive peptides are worthwhile to study. Among bioactive peptides, ACE inhibitors are of great importance in terms of hypertension. Since the hypertension is very common not only in developing countries but also in developed countries, it is very important to propose the ACE inhibitors for the production of functional food-based inhibitors. From this perspectives, isolated $P$. volitans toxins can be an alternative source of ACE inhibitors. After partial purification of these toxins, ACEinhibitors based bioactive peptide cocktails can be prepared. The stimulating is one of the parameters that BIOPEP provided. The stimulating in BIOPEP is defined as the peptides stimulating various biological processes (Minkiewicz et al., 2019). The information related to specific biological activities are also given for each individual protein. When two proteins are compared, it is clear from Table 2 and 3 that Pvtoxin-a has remarkable stimulating activities than Pvtoxin-b. Specific biological activities can be accessed from BIOPEP web page after enzymatic in silico digestion of these proteins. For example, after enzymatic digestion of Pvtoxin-a via trypsin, chymotrypsin and pepsin, VPL was found as a stimulating peptide. Its biological activities are matched with stimulating release of vasoactive substance with 327.41 chemical mass value. The antioxidative term in BIOPEP is defined as peptides inhibiting oxidation. When Pvtoxin-a and -b were compared, the differences in the $\mathrm{W}$ values were observed. On the other hand, their $\mathrm{A}_{\mathrm{E}}$ values were the same. According to Table 3, Pvtoxin-b has more antioxidative activities than Pvtoxin-a. After digestion of Pvtoxinb, SDF was found as an antioxidative peptide. AH and EL can also be given as examples for this activity. W and $A_{E}$ values of Pvtoxin-a and -b for Renin inhibitor were found same. SF and TF were found as renin inhibitor peptides after digestion of Pvtoxin-b. DPP-IV is a serine protease which catalyzes amide bonds. It is reported that DPP-4 inhibitors have an effect on diabetes type-II. Diabetes is a very common health issue and it is very common among 35-40 aged people (Misumi \& Ikehara, 2013). According to Table 2 and 3, when $\mathrm{A}_{\mathrm{E}}$ and $\mathrm{W}$ values were compared for the two proteins, Pvtoxin-a has more DPP-IV inhibitors than Pvtoxin-b. VP, PL, $\mathrm{AF}, \mathrm{AH}, \mathrm{DN}$ can be given as examples as DPP-IV inhibitor peptides. Dipeptidyl peptidase III (DPP-III) is a zinc-dependent hydrolase involved in degrading oligopeptides with 4-12 amino acid residues (Jha et al., 2020). When two proteins were compared, Pvtoxin-b had noticeably more DPP-III inhibitors than Pvtoxin-a. TF and PF can be given as examples for DPP-III inhibitor peptides. BLAST-p was used to find similar proteins. According to Figure 2, Pterois lunulata, Pterois antennata, Sebastes umbrosus, Sebastastiscus marmoratus, Sebastapistes strongia, Scorpaenopsis oxycephala, Dendrochirus zebra and Hypodytes rubripinnis have Pvtoxin-a like protein. Their percent identities were found to be between 98.57 and $70.67 \%$. The shortest sequence was found to be 583 in D. zebra and the longest sequence was 752 in S. umbrosus. According to Figure 3, Pvtoxin-b like protein was found in the genus Inimicus, Sebastepisces, Scorpaenopsis, Scorpaena, Sebastes, Sebastiscus, Dendrochrius and Hypodytes. When two proteins were compared, Tx gamma-subunit from D. zebra, Synanceia horrida, Synanceia verrucose, Sander lucioperca and Inimicus japonicus were observed for Pvtoxin-b. Most of these fishes belong to the Scorpaenidae family and they are distributed in tropical waters. 
Harris et al. (2020) tested the collapsible trap (Gittings trap) for mitigation of $P$. volitans. The trap technology is very important since SCUBA divers may not always access the depth limits of $P$. volitans. The authors tested their trap in the northern Gulf of Mexico. It is reported that 327 lionfish and 28 native fish were trapped. On the other hand, removal efficacy was given between as $12-24 \%$. According to the authors, even if this range is lower than that of spearfishing, more studies are recommended to develop the traps.

Sommeng et al. (2019) studied the antiviral activity of P.volitans phospholipase A2 (PLA2) from Indonesia for its effects on the human immunodeficiency virus. The authors reported that PLA2 from P.volitans showed strong inhibition on the SRV2-A549 cell lines, therefore, they suggested to evaluate their effects in vivo. Sommeng et al. (2020) also investigated the coagulant activity of P.volitans spine venom. The authors studied the coagulant activity via prothrombin time and activated partial thromboplastin time. They found out that the responsible procoagulant molecule in P.volitans venom is Nomega-nitro-L-arginine methyl ester. BecerraAmezcua et al. (2020) investigated the effects of the venom of P.volitans on the cholinergic and dopaminergic systems via nicotinic acetylcholine receptors and dopaminergic neurons. Zebra fish was used as a model organisms in their study and it was found by the authors that the venom from P.volitans significantly affected the dopaminergic neurons and retarded embryonic development due to the venom also affects growth hormone secretion. The authors also concluded that lionfish venom should be further studied for its possible pharmaceutical effects on the Alzheimers' disease.

Hoo Fung et al. (2013) investigated concentrations of essential, non-essential and toxic elements in the tissues of $P$. volitans collected from Jamaican waters. While the muscular tissues of the $P$. volitans (lionfish) were evaluated, researchers demonstrated that it might make a significant contribution as an alternative nutrition source since it did not reveal conceivably hazardous substances. This study appears partly to confirm the findings of our study. Cavas et al. (2020), in our previous study, proposed that the toxins of Lagocephalus sceleratus can be removed and the residues including toxins could be exploited in some industries such as pharmacy inasmuch as their analgesic and anti-cancer effects have been reported for these toxins. From the study of Cavas et al. (2020), it could be said that the removed toxins of $L$. sceleratus may also be evaluated in different industries such as pharmacy inasmuch as their analgesic and anti-cancer effects.

Galloway \& Porter (2019) studied the mechanical properties of $P$. volitans spines by quantifying the impacts of shape and tapering on the mechanical properties of the spine. Well-known mechanical properties such as Young's modulus, elastic energy store and flexural stiffness were studied by Galloway \& Porter (2019). Bending properties of the spines are also investigated in their study. The authors suggested that the mechanical properties of the spines are important in many functions such as defense, protection and intimidation.

\section{CONCLUSION}

From the published papers, it could be said that the systematic of the genera Pterois is very complex. Even if there has so far been a confusion in the taxonomic identification, the toxins mentioned in this paper most probably exist in P. miles which has colonized the Mediterranean Sea. After carefully removal of the venomous spines, the rest of the lionfish tissues can be consumed. From the results of the present study, it could be said that bioactive peptides exist in proteinaceous toxins of $P$. volitans and these bioactive peptides can be used as an alternative protein source. A possible economical values assigned to these invasive fishes may create extra stress on their populations and may help to control their populations. More studies on lionfish species, are strongly warranted to evaluate their values in the preparation of functional foods.

\section{CONFLICT OF INTEREST}

The authors declare no conflict of interest. 


\section{REFERENCES}

Agirbasli, Z., \& Cavas, L. (2017). In silico evaluation of bioactive peptides from the green algae Caulerpa. Journal of Applied Phycology, 29, 1635-1646. doi:10.1007/s10811-016-1045-7

Agyei, D., \& Danquah, M. K. (2012). Rethinking food-derived bioactive peptides for antimicrobial and immunomodulatory activities. Trends in Food Science and Technology, 23(2), 62-69. doi: $\underline{10.1016 / j . t i f s .2011 .08 .010}$

Altschul, S. F., Gish, W., Miller, W., Myers, E. W., \& Lipman, D. J. (1990). Basic local alignment search tool. Journal of Molecular Biology, 215(3), 403-410. doi:10.1016/S0022-2836(05)80360-2

Andradi-Brown, D. A. (2019). Invasive Lionfish (Pterois volitans and P. miles): Distribution, Impact, and Management. In: Y. Loya, K. A. Puglise, \& T. C. L. Bridge (Eds.) Mesophotic Coral Ecosystems (pp. 931941) Coral Reefs of the World book series (CORW, 12). Springer, Cham. doi:10.1007/978-3-319-92735-0_48

Antalya Büyükşehir Belediyesi. (2021, July 11) Akdeniz'de aslan balı̆̆ avı. (Accessed:10/09/2021) www.antalya.bel.tr/Haberler/HaberDetay/3294/akdenizde-aslan-baligi-avi

Ayas, D., Ağılkaya, G. Ş., \& Yağlığlu, D. (2018). New record of the red lionfish, Pterois volitans (Linnaeus, 1758), in the Northeastern Mediterranean Sea. Düzce Üniversitesi Bilim ve Teknoloji Dergisi, 6(4), 871-877. doi:10.29130/dubited.362703

Becerra-Amezcua, M. P., Hernández-Sámano, A. C., Puch-Hau, C., Aguilar, M. B., \& Collí-Dulá, R. C. (2020). Effect of Pterois volitans (lionfish) venom on cholinergic and dopaminergic systems. Environmental Toxicology and Pharmacology, 77, 103359. doi:10.1016/j.etap.2020.103359

Bédry, R., de Haro, L., Bentur, Y., Senechal, N., \& Galil, B. S. (2021). Toxicological risks on the human health of populations living around the Mediterranean Sea linked to the invasion of non-indigenous marine species from the Red Sea: A review. Toxicon, 191, 69-82. doi:10.1016/j.toxicon.2020.12.012

Carballo-Cárdenas, E. C. (2015). Controversies and consensus on the lionfish invasion in the western atlantic ocean. Ecology and Society, 20(3), 24. doi:10.5751/ES-07726-200324

Cavas, L., Bilgin, Y., \& Yilmaz-Abeska, Y. (2020). Can bioactive peptides of Lagocephalus sceleratus be evaluated in the functional food industry? Biotech Studies, 29(2), 77-84. doi:10.38042/biost.2020.29.02.04

Chakrabarti, S., Guha, S., \& Majumder, K. (2018). Food-derived bioactive peptides in human health: Challenges and opportunities. Nutrients, 10(11), 1-17. doi:10.3390/nu10111738

Çinar, M. E., Bilecenoğlu, M., Yokeş, M. B., Öztürk, B., Taşkin, E., Bakir, K., Doğan, A., \& Açik, Ş. (2021). Current status (as of end of 2020) of marine alien species in Turkey, PLoS ONE, 16(5), 1-46, e0251086. doi:10.1371/journal.pone.0251086

Dağhan, H., \& Demirhan, S. A. (2020). Some bio-ecological characteristics of lionfish Pterois miles (Bennett, 1828) in Iskenderun Bay. Marine Life Science, 2(1), 28-40.

Daroit, D. J., \& Brandelli, A. (2021). In vivo bioactivities of food protein-derived peptides - a current review. Current Opinion in Food Science, 39, 120-129. doi:10.1016/j.cofs.2021.01.002

Davis, A. (2016). The Consumption of Lionfish as a Control of an Invasive Species in Bermuda. Undergraduate Honors Theses, 1045.

Ferreira, C. E. L., Luiz, O. J., Floeter, S. R., Lucena, M. B., Barbosa, M. C., Rocha, C. R., \& Rocha, L. A. (2015). First record of invasive lionfish (Pterois volitans) for the Brazilian coast. PLoS ONE, 10(4), 1-5, e0123002. doi:10.1371/journal.pone.0123002

Galloway, K. A., \& Porter, M. E. (2019). Mechanical properties of the venomous spines of Pterois volitans and morphology among lionfish species. Journal of Experimental Biology, 222(6). doi:10.1242/jeb.197905

Gasteiger, E., Hoogland, C., Gattiker, A., Duvaud, S., Wilkins, M. R., Appel, R. D., \& Bairoch, A. (2005). Protein identification and analysis tools on the ExPASy server. In: J. M. Walker (Eds.) The Proteomics Protocols Handbook (pp. 571-607). Humana Press. 
Gürlek, M., Ergüden, D., Uyan, A., Doğdu, S. A., Yağlığlu, D., Öztürk, B., \& Turan, C. (2016). First record red lionfish Pterois volitans (Linnaeus, 1785) in the Mediterranean Sea. Natural and Engineering Sciences, 4(1), 64-75. doi:10.28978/nesciences.286308

Harris, H. E., Fogg, A. Q., Gittings, S. R., Ahrens, R. N. M., Allen, M. S., \& Patterson, W. F. (2020). Testing the efficacy of lionfish traps in the northern Gulf of Mexico. PLoS ONE, 15(8), 1-20, e0230985. doi: $10.1371 /$ journal.pone.0230985

Hoo Fung, L. A., Antoine, J. M. R., Grant, C. N., \& Buddo, D. S. A. (2013). Evaluation of dietary exposure to minerals, trace elements and heavy metals from the muscle tissue of the lionfish Pterois volitans (Linnaeus 1758). Food and Chemical Toxicology, 60, 205-212. doi:10.1016/j.fct.2013.07.044

Jang, A., \& Lee, M. (2005). Purification and identification of angiotensin converting enzyme inhibitory peptides from beef hydrolysates. Meat Science, 69(4), 653-661. doi:10.1016/j.meatsci.2004.10.014

Jha, S., Taschler, U., Domenig, O., Poglitsch, M., Bourgeois, B., Pollheimer, M., Pusch, L. M., Malovan, G., Frank, S., Madl, T., Gruber, K., Zimmermann, R., \& Macheroux, P. (2020). Dipeptidyl peptidase 3 modulates the renin-Angiotensin system in mice. Journal of Biological Chemistry, 295(40), 13711-13723. doi:10.1074/jbc.RA120.014183

Kandemir-Cavas, C., Pérez-Sánchez, H., Mert-Ozupek, N., \& Cavas, L. (2019). In Silico Analysis of Bioactive Peptides in Invasive Sea Grass Halophila stipulacea. Cells, 8(6), 557. doi:10.3390/cells8060557

Kleitou, P., Savva, I., Kletou, D., Hall-Spencer, J. M., Antoniou, C., Christodoulides, Y., Chartosia, N., Hadjioannou, L., Dimitriou, A. C., Jimenez, C., Petrou, A., Sfenthourakis, S., \& Rees, S. (2019). Invasive lionfish in the Mediterranean: Low public awareness yet high stakeholder concerns. Marine Policy, 104, 6674. doi:10.1016/j.marpol.2019.02.052

Kiriake, A., \& Shiomi, K. (2011). Some properties and cDNA cloning of proteinaceous toxins from two species of lionfish (Pterois antennata and Pterois volitans). Toxicon, 58(6-7), 494-501. doi:10.1016/j.toxicon.2011.08.010

Kovačić, M., Lipej, L., Dulčić, J., Iglesias, S. P., \& Goren, M. (2021). Evidence-based checklist of the Mediterranean Sea fishes. Zootaxa, 4998(1), 1-115. doi:10.11646/zootaxa.4998.1.1

Liu, L., Li, S., Zheng, J., Bu, T., He, G., \& Wu, J. (2020). Safety considerations on food protein-derived bioactive peptides. Trends in Food Science and Technology, 96, 199-207. doi:10.1016/j.tifs.2019.12.022

Livaneli, Z. (2021). Balıkçı ve Oğlu (1st ed.). İnkılap Kitabevi. İstanbul.

Meister, H. S., Wyanski, D. M., Loefer, J. K., Ross, S. W., Quattrini, A. M., \& Sulak, K. J. (2005). Further evidence for the invasion and establishment of Pterois volitans (Teleostei: Scorpaenidae) along the Atlantic Coast of the United States. Southeastern Naturalist, 4(2), 193-206. doi:10.1656/15287092(2005)004[0193:FEFTIA]2.0.CO;2

Minkiewicz, P., Iwaniak, A., \& Darewicz, M. (2019). BIOPEP-UWM database of bioactive peptides: Current opportunities. International Journal of Molecular Sciences, 20(23). doi:10.3390/ijms20235978

Misumi, Y., \& Ikehara, Y. (2013). Dipeptidyl-peptidase IV. In: N. D. Rawlings, \& G. Salvesen (Eds.) Handbook of Proteolytic Enzymes (Vol. 3), (3rd ed., pp. 3374-3379). doi:10.1016/B978-0-12-3822192.00745-6

Morgat, A., Lombardot, T., Coudert, E., Axelsen, K., Neto, T. B., Gehant, S., Bansal, P., Bolleman, J., Gasteiger, E., de Castro, E., Baratin, D., Pozzato, M., Xenarios, I., Poux, S., Redaschi, N., Bridge, A., \& The UniProt Consortium. (2020). Enzyme annotation in UniProtKB using Rhea. Bioinformatics, 36(6), 1896-1901. doi:10.1093/bioinformatics/btz817

Nair, M. S. R., Cheung, P., Leong, I., \& Ruggieri, G. D. (1985). A non-proteinaceous toxin from the venomous spines of the Lionfish Pterois volitans (Linnaeus). Toxicon, 23(3), 525-527. doi:10.1016/0041$\underline{0101(85) 90037-6}$ 
Sievers, F., Wilm, A., Dineen, D., Gibson, T. J., Karplus, K., Li, W., Lopez R., McWilliam H., Remmert M., Söding J., \& Thompson, J. D. (2011). Fast, scalable generation of high-quality protein multiple sequence alignments using Clustal Omega. Molecular Systems Biology, 7(1), 539. doi:10.1038/msb.2011.75

Sommeng, A. N., Arya, R. M. Y., Ginting, M. J., Pratami, D. K., Hermansyah, H., Sahlan, M., \& Wijanarko, A. (2019). Antiretroviral activity of Pterois volitans (red lionfish) venom in the early development of human immunodeficiency virus/acquired immunodeficiency syndrome antiretroviral alternative source. Veterinary World, 12(2), 309-315. doi:10.14202/vetworld.2019.309-315

Sommeng, A. N., Eka, A. K., Ramadhan, M. Y. A., Ginting, M. J., Sahlan, M., Hermansyah, H., \& Wijanarko, A. (2020). Protein isolation and identification of Pterois volitans spine venom coagulant activity. IOP Conference Series: Earth and Environmental Science, 462, 012039. doi:10.1088/1755-1315/462/1/012039

Schofield, P. J. (2009). Geographic extent and chronology of the invasion of non-native lionfish (Pterois volitans [Linnaeus 1758] and P. miles [Bennett 1828]) in the western North Atlantic and Caribbean Sea. Aquatic Invasions, 4(3), 473-479. doi:10.3391/ai.2009.4.3.5

Schofield, P. J. (2010). Update on geographic spread of invasive lionfishes (Pterois volitans [Linnaeus, 1758] and P. miles [Bennett, 1828]) in the western North Atlantic Ocean, Caribbean Sea and Gulf of Mexico. Aquatic Invasions, 5, 117-122. doi:10.3391/ai.2010.5.S1.024

Sutherland, W. J., Clout, M., Côté, I. M., Daszak, P., Depledge, M. H., Fellman, L., Fleishman, E., Garthwaite, R., Gibbons, D. W., De Lurio, J., Impey, A. J., Lickorish, F., Lindenmayer, D., Madgwick, J., Margerison, C., Maynard, T., Peck, L. S., Pretty, J., Prior, S., Redford, K. H., Scharlemann, J. P. W., Spalding, M., \& Watkinson, A. R. (2010). A horizon scan of global conservation issues for 2010. Trends in Ecology \& Evolution, 25(1), 1-7. doi:10.1016/J.TREE.2009.10.003

Turan, C., Uygur, N., \& İğde, M. (2017). Lionfishes Pterois miles and Pterois volitans in the North-eastern Mediterranean Sea: Distribution, habitation, predation and predators. Natural and Engineering Sciences, 2(1), 35-43. doi:10.28978/nesciences.292355

Turan, C., Uyan, A., Gürlek, M., \& Doğdu, S. A. (2020). DNA Barcodes for Identifications of Two Lionfish Species Pterois miles (Bennett, 1828) and Pterois volitans (Linnaeus, 1758) in the Mediterranean. FishTaxa, $16,29-36$.

Ulman, A., Tunçer, S., Kizilkaya, I. T., Zilifli, A., Alford, P., \& Giovos, I. (2020). The lionfish expansion in the Aegean Sea in Turkey: A looming potential ecological disaster. Regional Studies in Marine Science, 36, 101271. doi:10.1016/j.rsma.2020.101271

Vetrano, S. J., Lebowitz, J. B., \& Marcus, S. (2002). Lionfish envenomation. Journal of Emergency Medicine, 23(4), 379-382. doi:10.1016/s0736-4679(02)00572-3

Weaver, C. M. (2014). Bioactive foods and ingredients for health. Advances in Nutrition, 5(3), 306S-311S. doi:10.3945/an.113.005124

Yuzvik, A., Kelly, B. R., Lombardi, J. P., Uvarov, N. A., \& Godsey, W. G. (2018). Autonomous Lionfish Harvester. Worcester Polytechnic Institute. https://digitalcommons.wpi.edu/mqp-all/2499

Zhou, J., Chen, M., Wu, S., Liao, X., Wang, J., Wu, Q., Zhuang, M., \& Ding, Y. (2020). A review on mushroom-derived bioactive peptides: Preparation and biological activities. Food Research International, 134, 109230. doi:10.1016/j.foodres.2020.109230 